\title{
A review on technology maturity of small scale energy storage technologies ${ }^{\star}$
}

\author{
Thu-Trang Nguyen ${ }^{1,}$, Viktoria Martin ${ }^{1}$, Anders Malmquist ${ }^{1}$, and Carlos A.S. Silva ${ }^{2}$ \\ ${ }^{1}$ KTH Royal Institute of Technology, Stockholm, Sweden \\ ${ }^{2}$ Instituto Superior Técnico, Universidade de Lisboa, Lisbon, Portugal
}

Received: 16 January 2017 / Received in final form: 8 July 2017 / Accepted: 27 July 2017

\begin{abstract}
This paper reviews the current status of energy storage technologies which have the higher potential to be applied in small scale energy systems. Small scale energy systems can be categorized as ones that are able to supply energy in various forms for a building, or a small area, or a limited community, or an enterprise; typically, they are end-user systems. Energy storage technologies are classified based on their form of energy stored. A twostep evaluation is proposed for selecting suitable storage technologies for small scale energy systems, including identifying possible technical options, and addressing techno-economic aspects. Firstly, a review on energy storage technologies at small scale level is carried out. Secondly, an assessment of technology readiness level (TRL) is conducted. The TRLs are ranked according to information gathered from literature review. Levels of market maturity of the technologies are addressed by taking into account their market development stages through reviewing published materials. The TRLs and the levels of market maturity are then combined into a technology maturity curve. Additionally, market driving factors are identified by using different stages in product life cycle. The results indicate that lead-acid, micro pumped hydro storage, NaS battery, NiCd battery, flywheel, $\mathrm{NaNiCl}$ battery, Li-ion battery, and sensible thermal storage are the most mature technologies for small scale energy systems. In the near future, hydrogen fuel cells, thermal storages using phase change materials and thermochemical materials are expected to become more popular in the energy storage market.
\end{abstract}

\section{Introduction}

Energy storage is considered to play a critical role in the futures of energy systems, particularly electricity systems, since it can improve the management of distribution networks, reducing costs and improving efficiency. In general, energy storage technologies can be classified by their functions or forms of energy stored in the system. This paper categorizes energy storage technologies based on the form of the stored energy, namely electrical energy storage (supercapacitors; superconducting magnetic energy storage), mechanical energy storage (pumped hydro; compressed air; flywheels), chemical energy storage (batteries; flow batteries; hydrogen fuel cells and metalair batteries; solar fuels), and thermal energy storage (sensible heat storage; latent heat storage; thermochemical heat storage) $[1,2]$.

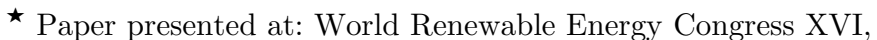
5-9 February 2017, Murdoch University, Western Australia.

* e-mail: nguyentt@kth.se
}

In this paper, we focus on applications for small scale systems. Small scale energy systems can be categorized as ones that are able to supply energy in various forms for a building, or a small area, or a limited community, or an enterprise; typically, they are end-user systems. Capacity of the systems normally can be expected as less than $1 \mathrm{MW}$ for electricity, or a few MW in terms of thermal supply [3]. A large number of reviews on different energy storage types for various systems can be found, i.e., [1,2,4-13]. These reviews have been normally done with regard to systems at medium or large scale, but very a few of them specify technology choices for small scale energy systems. Also, other papers tend to present some certain types of energy storage for particular applications at small scale level, such as [14-17]. Thus, there is a need for a systemic review of energy storage technologies for small scale energy systems. Furthermore, current selection of energy storage technologies is mainly influenced by technical specifications of the systems, with market review being included limitedly. This paper, therefore, aims at providing an overview on storage technologies that are suitable for small scale energy systems, and proposing a holistic way of selecting storage technology for small scale energy systems, with technology maturity and market development being taken into consideration. 


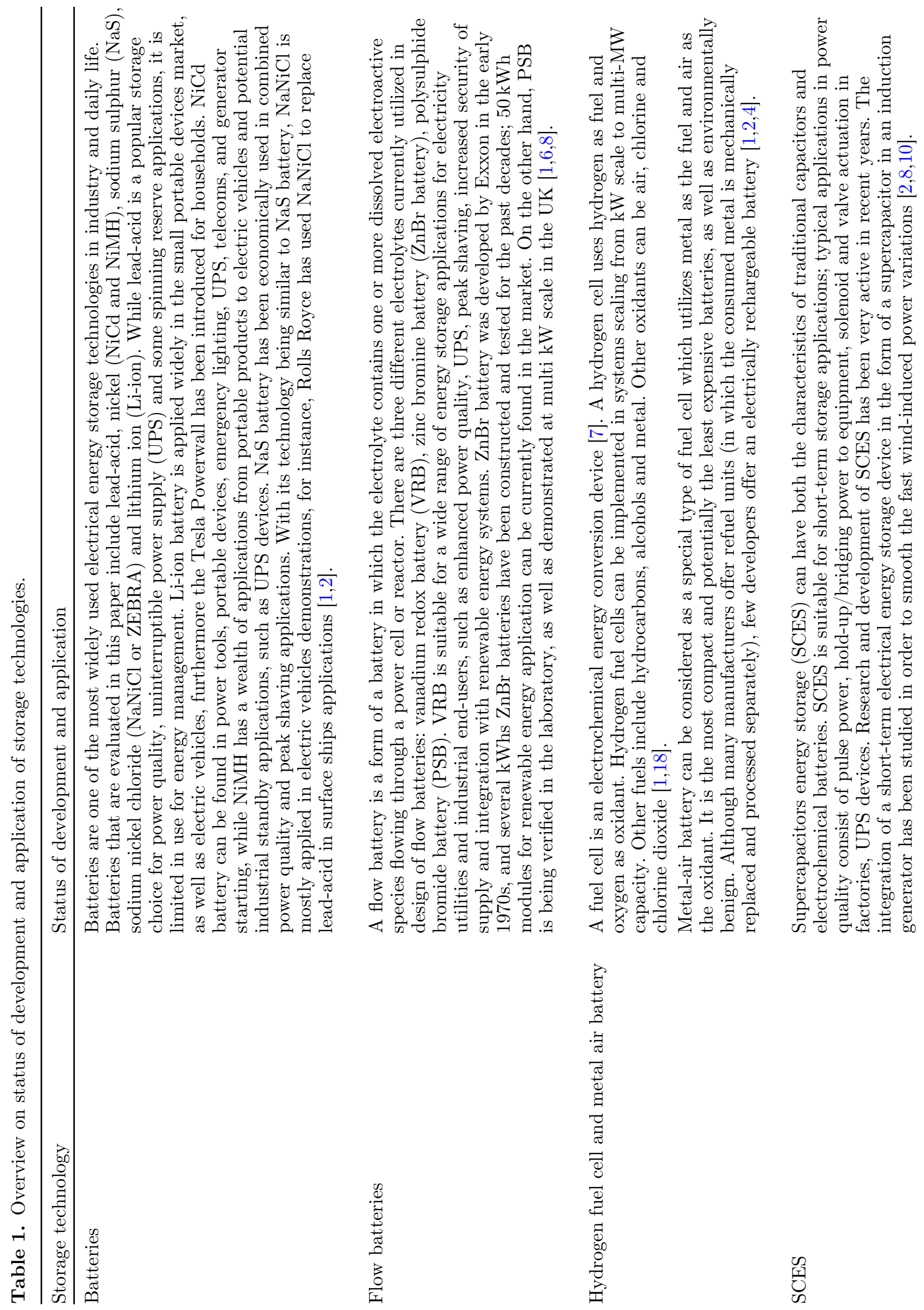




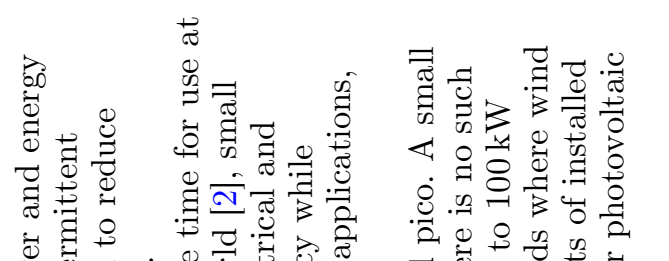

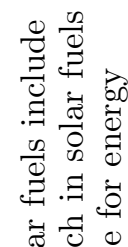

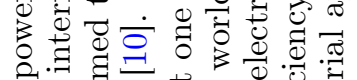

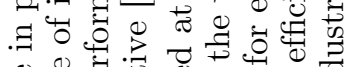

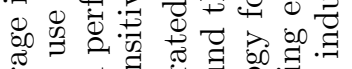

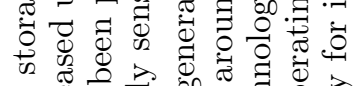

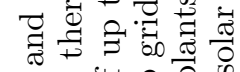

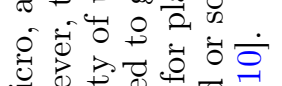

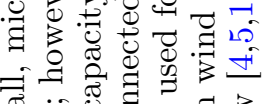

व

可.

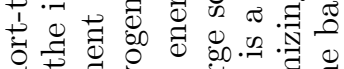

कृ

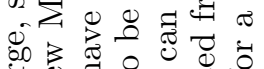

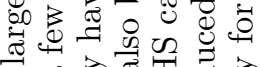

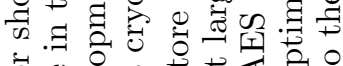

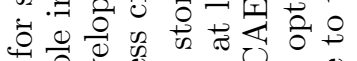

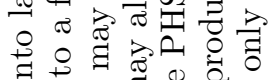

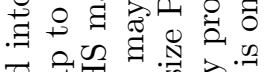

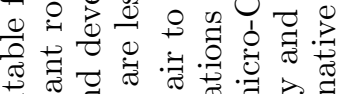

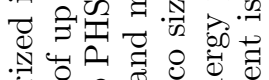

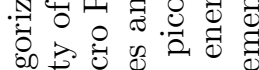

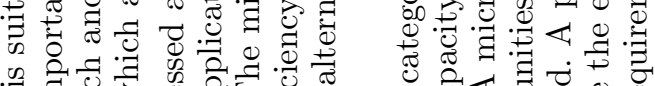

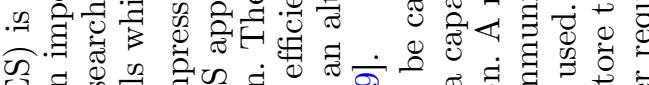

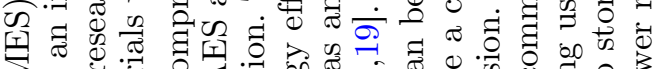

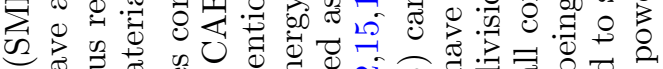
可

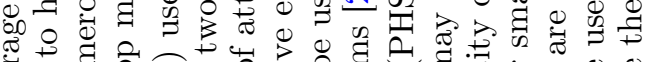

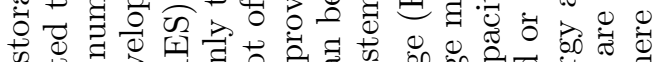

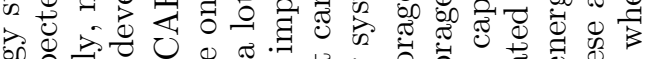
on

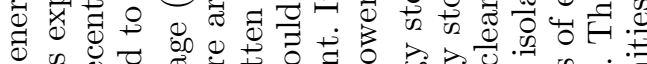

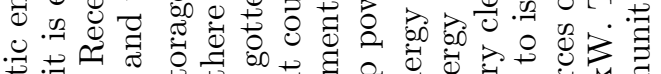

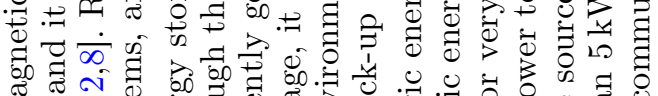
छै

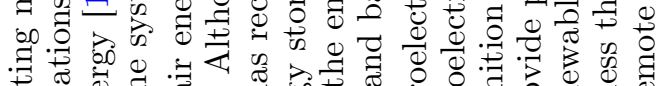

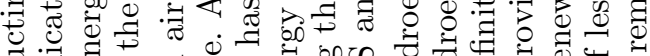

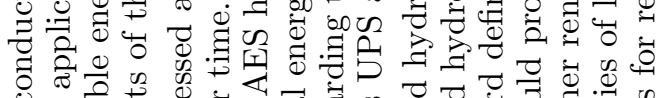

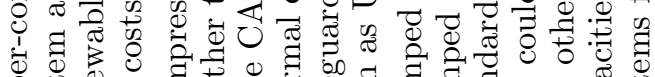

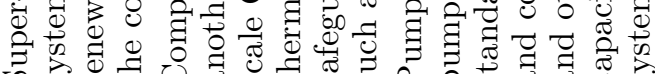
.

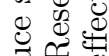

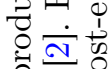

过

की

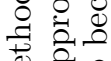

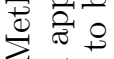

규.

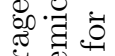

के

bo

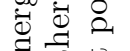

శึ

要

记

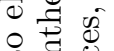

구이

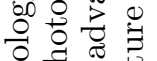

至吾

疋.

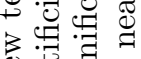

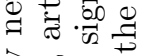

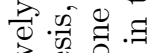

.

월

๙

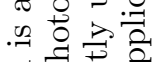

Ф

巴西兽

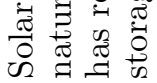

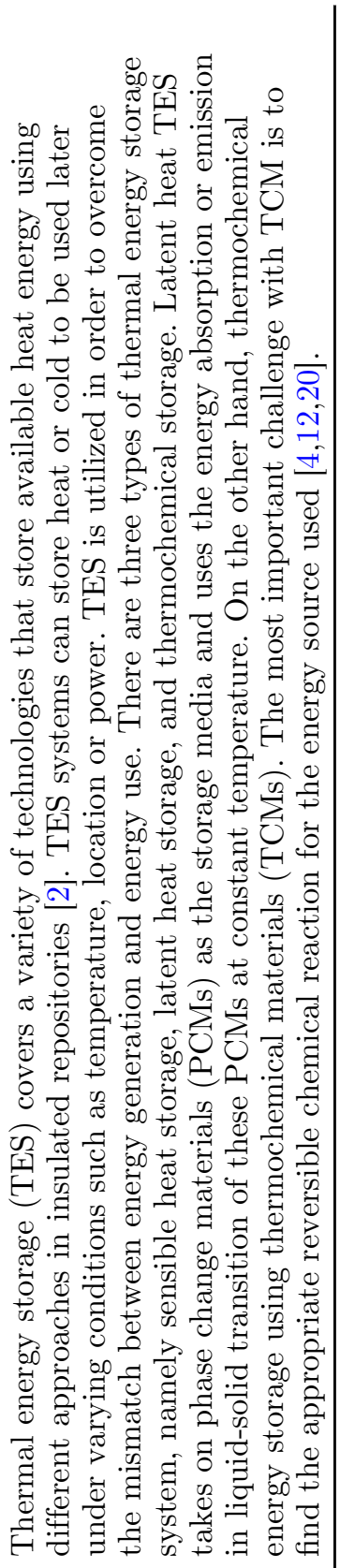


Table 2. Characteristics of small scale energy storage technologies.

\begin{tabular}{|c|c|c|c|c|c|c|c|c|}
\hline $\begin{array}{l}\text { Storage } \\
\text { technology }\end{array}$ & $\begin{array}{l}\text { Power } \\
\text { rating, } \\
\text { MW }\end{array}$ & $\begin{array}{l}\text { Energy } \\
\text { rating }\end{array}$ & $\begin{array}{l}\text { Respons } \\
\text { time }\end{array}$ & $\begin{array}{l}\text { Suitable storage } \\
\text { duration }\end{array}$ & $\begin{array}{l}\text { e Energy } \\
\text { density, } \\
\mathrm{Wh} / \mathrm{kg}\end{array}$ & $\begin{array}{l}\text { Power density, } \\
\mathrm{W} / \mathrm{kg}\end{array}$ & $\begin{array}{l}\text { Operating } \\
\text { temperature, } \\
{ }^{\circ} \mathrm{C}\end{array}$ & $\begin{array}{l}\text { Self-discharge, } \\
\% / \text { day }\end{array}$ \\
\hline Micro PHS 0 & $0-0.1$ & $1-24 \mathrm{~h}+$ & $\mathrm{s}-\min$ & Hours-months & $0.5-1.5$ & & & $\approx 0$ \\
\hline Micro CAES L & Up to 1 & $1-24 \mathrm{~h}+$ & $5-15 \mathrm{~min}$ & Hours-months & $30-60$ & & & $\approx 0$ \\
\hline $\begin{array}{l}\text { Hydrogen } \\
\text { fuel cell }\end{array}$ & $0.001-50$ & $\mathrm{~s}-24 \mathrm{~h}+$ & $\min$ & Hours-months & $800-104$ : & $500+$ & & $0.5-2$ \\
\hline Metal air & $0-0.01$ & & $\mathrm{~s}-24 \mathrm{~h}+$ & Hours-months & & & & Very small \\
\hline Solar fuels & $0-10$ & & $1-24 \mathrm{~h}+$ & Hours-months & & & & $\approx 0$ \\
\hline Fly-wheels & $0.002-20$ & $15 \mathrm{~s}-15 \mathrm{~min}$ & & & $5-130$ & $400-1600$ & -60 & $20-100$ \\
\hline SMES & $0.01-10$ & $\mathrm{~ms}-5 \mathrm{~min}$ & $\mathrm{~ms}$ & & $0.5-5$ & $500-2000$ & & $10-15$ \\
\hline SCES & $0.01-1$ & $\mathrm{~ms}-1 \mathrm{~h}$ & $\mathrm{~ms}$ & & $0.1-15$ & $0.1-10$ & -125 & $2-40$ \\
\hline Lead-acid & $0.001-50$ & $\mathrm{~s}-3 \mathrm{~h}$ & & Minutes-days & $30-50$ & $75-300$ & & $0.1-0.3$ \\
\hline Li-ion & $0.001-0.1$ & $\min -\mathrm{h}$ & & Minutes-days & $75-250$ & $150-315$ & & $0.1-0.3$ \\
\hline $\mathrm{NiCd}$ & $0.001-40$ & $\mathrm{~s}-\mathrm{h}$ & & Minutes-days & $40-60$ & $150-300$ & & $0.2-0.6$ \\
\hline $\mathrm{NaS}$ & $0.5-50$ & $\mathrm{~s}-\mathrm{h}$ & & Seconds-hours & $150-240$ & $90-230$ & $300-350$ & 20 \\
\hline ZEBRA & $0.001-1$ & $\min -\mathrm{h}$ & & Seconds-hours & 125 & $130-160$ & 300 & 15 \\
\hline VRB & $0.03-7$ & $\mathrm{~s}-10 \mathrm{~h}$ & $\mathrm{~ms}$ & Hours-months & 75 & & $0-40$ & $0-10$ \\
\hline $\mathrm{ZnBr}$ & $0.05-2$ & $\mathrm{~s}-10 \mathrm{~h}$ & $\mathrm{~ms}$ & Hours-months & $60-80$ & $50-150$ & & 1 \\
\hline PSB & $0.001-0.015$ & & $\mathrm{~s}-10 \mathrm{~h}$ & Hours-months & & & & \\
\hline Sensible TES 0 & $0.001-280$ & & $1-8 \mathrm{~h}$ & Hours-months & $80-120$ & & & $<1$ \\
\hline PCM & $0.001-1$ & & & Minutes-month & is $50-150$ & & & \\
\hline TCM & $0.001-1$ & & & Minutes-days & $120-250$ & & & \\
\hline $\begin{array}{l}\text { Storage } \\
\text { technology }\end{array}$ & $\begin{array}{l}\text { Round-trix } \\
\text { efficiency }\end{array}$ & ip $\begin{array}{l}\text { Life ti } \\
\text { years }\end{array}$ & & ycles & $\begin{array}{l}\text { Oower } \\
\text { ost, } \\
\text { JSD } / \mathrm{kW}\end{array}$ & $\begin{array}{l}\text { Energy } \\
\text { cost, } \\
\text { USD } / \mathrm{kWh}\end{array}$ & $\begin{array}{l}\text { Capital cost, } \\
\text { UScent } / \mathrm{kW} \\
\text { / cycle }\end{array}$ & $\begin{array}{l}\text { O\&M } \\
\text { cost, } \\
\text { USD } / \mathrm{kWh} \\
\end{array}$ \\
\hline Micro PHS & $75-85$ & $50-10$ & & $\times 10^{4}-5 \times 10^{4}$ & $50-4000$ & $65-165$ & $0.1-1.4$ & 0.004 \\
\hline Micro CAES & $42-54$ & $25-40$ & & $\times 10^{3}-2 \times 10^{4}$ & $40-1280$ & $11-130$ & $2-4$ & \\
\hline $\begin{array}{l}\text { Hydrogen fuel } \\
\text { cell }\end{array}$ & $20-50$ & $5-15$ & & $3+$ & $10-1770$ & $1-16$ & $6000-20000$ & $0.0019-0.0153$ \\
\hline \multicolumn{9}{|l|}{ Metal air } \\
\hline \multicolumn{9}{|l|}{ Solar fuels } \\
\hline Fly-wheels & $85-95$ & $20+$ & & ${ }^{5}-10^{7}$ & $10-330$ & $1105-3870$ & $3-25$ & $\approx 0.004$ \\
\hline SMES & 95 & 20 & 10 & & $10-440$ & $770-7740$ & & 0.001 \\
\hline SCES & $85-98$ & $20+$ & & ${ }^{4}-10^{6}$ & $10-440$ & $330-4430$ & $2-20$ & 0.005 \\
\hline Lead-acid & $3-15$ & $100-10$ & & $0-650$ & $5-330$ & $22-110$ & $\approx 50^{\mathrm{a}}$ & \\
\hline Li-ion & $5-15$ & $10^{3}-10$ & & $0-3000$ & $20-1990$ & $16-110$ & & \\
\hline $\mathrm{NiCd}$ & $15-20$ & $1000-3$ & $3000 \quad 35$ & $0-1000$ & $20-1105$ & $22-110$ & $\approx 20^{\mathrm{a}}$ & \\
\hline $\mathrm{NaS}$ & $10-15$ & $2000-4$ & $4500 \quad 70$ & $0-2000$ & $20-995$ & $9-22$ & $\approx 80^{\mathrm{a}}$ & \\
\hline ZEBRA & $10-14$ & $2500+$ & & $0-200$ & $5-165$ & $5-11$ & & \\
\hline VRB & $5-20$ & $10^{4}+$ & 25 & 00 & $10-1105$ & $5-88$ & $\approx 70^{\mathrm{a}}$ & \\
\hline $\mathrm{ZnBr}$ & $5-10$ & $2000+$ & & $0-1800$ & $10-775$ & 5-88 & & \\
\hline PSB & & & & & & $5-88$ & & \\
\hline Sensible TES & $10-20$ & & & $0-3000$ & & $0.1-11$ & & \\
\hline PCM & $5-15$ & & & & & $11-57$ & & \\
\hline TCM & $5-15$ & & & $00-3000$ & & $9-112$ & & \\
\hline
\end{tabular}

${ }^{a} \mathrm{USD} / \mathrm{kW} /$ year. Data taken from $[1,2,4,6,10,20-22]$. Exchange rate between EUR and USD based on the average monthly rate in 2016, $1 \mathrm{EUR}=1.106 \mathrm{USD}$, data retrieved from http://www.x-rates.com/average/. 
T-T Nguyen et al.: Renew. Energy Environ. Sustain. 2, 36 (2017)

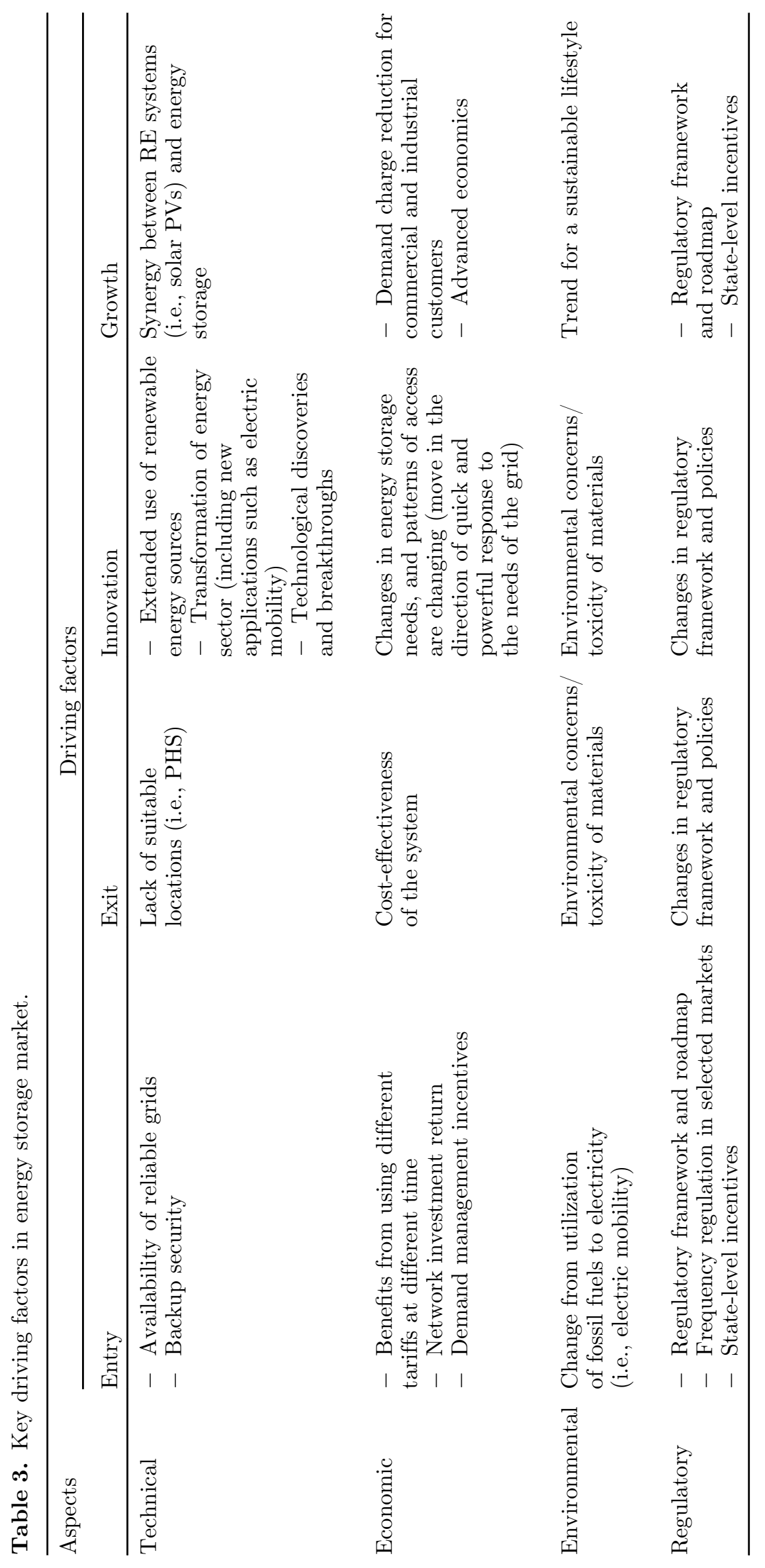




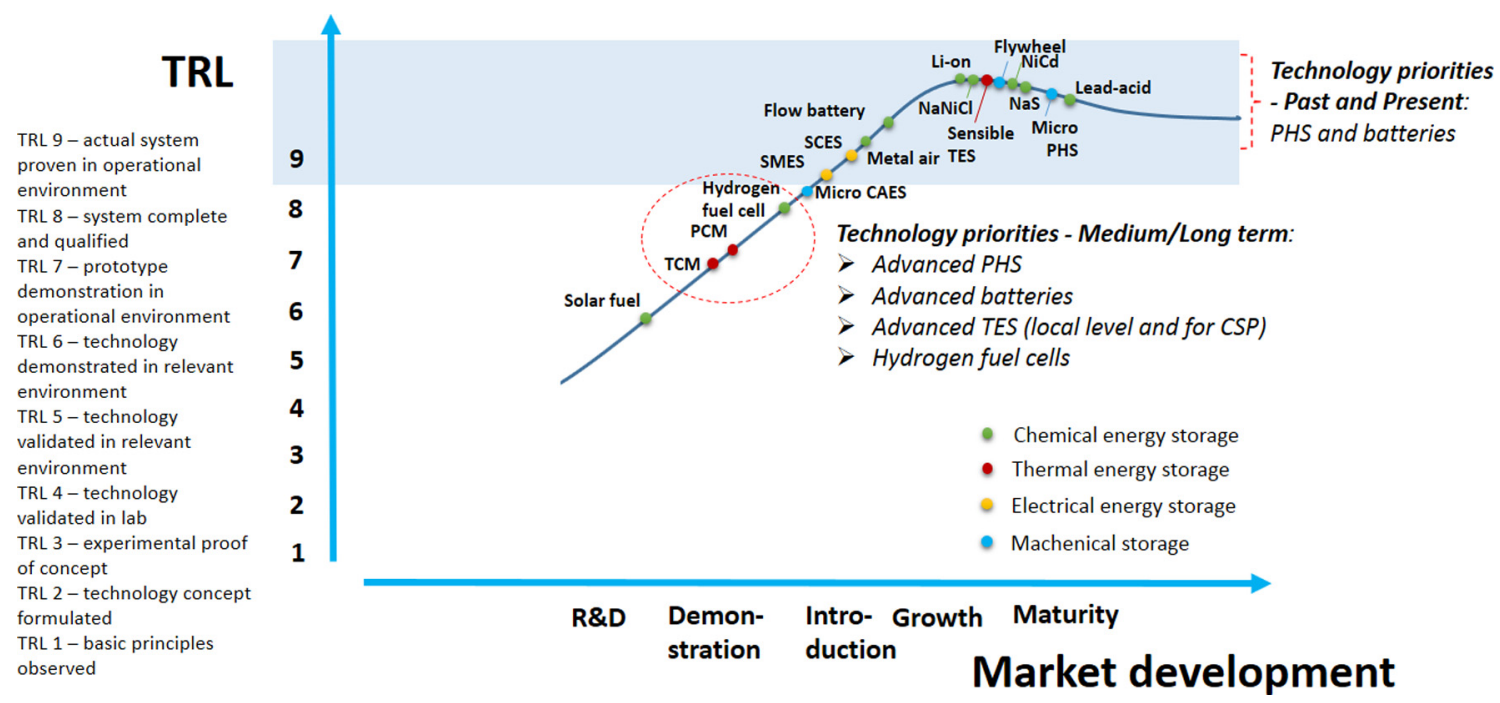

Fig. 1. Technology maturity curve of energy storage technologies for small scale energy systems. Data extracted and analysed from [2$4,6,10,12,20,24,26,31]$.

\section{Energy storage types for small scale energy systems}

With the advancements in energy storage technologies, almost all storage technologies can be applied at small scale level. These technologies are identified in the aforementioned classification, with micro compress air storage and micro pumped hydro storage being included, instead of their large-scale forms. This section will provide an overview on current development and application of energy storage technologies for small scale systems, as displayed in Table 1. While the overview does not focus on the configuration of the technologies, their characteristics are presented in Table 2 .

\section{Methodology}

With significant improvements in energy technology field for the past decades, it is important to include level of technology maturity, as well as priorities in research and development $(\mathrm{R} \& \mathrm{D})$ in the domain, when it comes to selecting storage technology for energy systems. This paper proposes a two-step evaluation for selecting suitable energy storage technology for small scale energy systems, as described in the following subsections.

\subsection{Step 1: Identify possible technical options}

In this step, by looking at technical requirements of the concerned system, possible technical options will be addressed. The technical characteristics of different storage technologies are compiled from available publications, including scientific papers, reports from established organizations. Table 2 summarizes technical and economic features of these technologies.

\subsection{Step 2: Address techno-economic aspects}

Techno-economic aspects mentioned in this section include methods to identify key driving factors and to illustrate technology maturity curve of the technologies, as well as sources for market forecast. By considering these assessments, a technology with suitable level of maturity or being one of the technology priorities can be chosen from the possible technical options.

\subsubsection{Methods for reviewing the energy storage market}

This paper applies principles in market dynamics analysis and literature review to address driving factors in the energy storage market. Within the framework of product life cycle, the stages of entry, exit, growth, and innovation of all energy storage types are investigated [23]. By reviewing revolutions in the market of energy storage following this product life cycle, driving factors which are responsible for the entry, exit, innovation, and growth of the storage technologies are identified and divided into four aspects, namely technical, economic, environmental, and regulatory. The review is based on several sources, from journal papers, international reports to economic journals, i.e., $[3,4,7,12,24-26]$. Additionally, market forecast for energy storage takes into account technology priorities from the past to the present, and projections for the direction of energy storage development in the future from available articles and official reports, in order to describe a general picture of the energy storage market in the next years. Finally, it is noticed that life cycle cost assessment is not included in the scope of this paper.

\subsubsection{Methods for constructing the technology maturity curve}

Technology maturity curve is depicted by assessing two parameters for each storage technology: technology readiness level (TRL) and stage of market development. The TRLs are a type of measurement system used to assess the maturity level of a particular technology. There are nine TRLs, where TRL 1 is the lowest and TRL 9 is the highest [27]. Based on the description of the levels, the TRL of each storage technology is recognized by investigating different reviews on energy storage technologies where the current state of technology development is marked; in case 
there are several references, the more recently released one is chosen. At the same time, stages of market development are evaluated according to $\mathrm{R} \& \mathrm{D}$, demonstration, introduction, growth, and maturity. Similar to the evaluation of the TRLs, a compilation of numerous references is conducted, not only from literature, but also from searching for real applications in the market.

\section{Results and discussions}

In this section, results are presented, along with discussions.

\subsection{Energy storage market review}

Identified driving factors that dominate the energy storage market are displayed in Table 3. As can be seen in the table, technical, economic, and regulatory factors play a critical role in shaping the energy storage market. However, environmental concerns have also contributed to transiting the market. Technology priorities in the field of energy storage are indicated in Figure $1[3,24,28]$. According to [26], by 2030 , the most attractive business opportunities are on decentralized island/off-grid storage. Other interesting business cases include applications in centralized conventional stabilization and centralized balancing energy, decentralized transmission and distribution deferral and industrial peak, and centralized black-start. Energy storage will be one key technology for the future, and its market volume value is expected to increase dramatically over the next few decades. However, there is a large difference in the predictions from different reports and statements. For instance, a study from [29] reported a projection from US analysts Pike Research that the potential market for energy storage systems could be about 122 billion USD by 2021, of which, they estimated the market potential for molten salt thermal energy storage for 2020 to be at least 1 billion USD.

\subsection{Technology maturity curve}

Figure 1 illustrates current status of energy storage technologies based on evaluation of their TRLs and stages of market development. The fact that market development for a mature technology declines over time is displayed by the curve. Compare this curve with the report conducted by [30], almost all storage technologies analysed in this paper are ranked similarly; the curve in this paper added solar fuel, micro CAES, micro PHS, PCM, and TCM. Regarding PCM and TCM thermal storages, their levels of maturity presented here are almost identical to that in the work done by [22].

\subsection{Discussion for the selection process}

The technology maturity curve implies that for small scale electricity systems, lead-acid, micro PHS, NaS battery, $\mathrm{NiCd}$ battery, flywheel, $\mathrm{NaNiCl}$ battery, Li-ion battery are the most mature technologies, thus implementation of these storages will likely meet with less difficulties, while implementing micro CAES, flow battery, metal air, SCES and SMES may be more complicated, since they are less experienced in the market. On the other hand, hydrogen fuel cells can be chosen as the technology for the near future, while solar fuels can be considered at a later time. With regard to small scale thermal systems, sensible thermal storage is a well proven choice; however, in the next decade, PCM and TCM are expected to become more popular in the market.

\section{Conclusions}

The review indicates that selection of an energy storage technology for energy systems should be based on not only technical requirements for the systems, but also maturity level of the storage technology level in the energy storage market, priorities in research and implementation, driving factors in the market. To conduct this, the paper proposes a two-step evaluation: identifying possible technical options and addressing techno-economic aspects. Lead-acid, micro PHS, NaS battery, NiCd battery, flywheel, NaNiCl battery, Li-ion battery, and sensible thermal storage are the most mature technologies for small scale energy systems. In the future, hydrogen fuel cells, PCM, and TCM are expected to grow considerably in the energy storage market.

This research has been done in collaboration with KTH, Royal Institute of Technology and IST, Instituto Superior Técnico funded through Erasmus Mundus Joint Doctoral Programme SELECT + , the support of which is gratefully acknowledged.

\section{References}

1. H. Chen, T.N. Cong, W. Yang, C. Tan, Y. Li, Y. Ding, Progress in electrical energy storage system: a critical review, Prog. Nat. Sci. 19, 291 (2009)

2. X. Luo, J. Wang, M. Dooner, J. Clarke, Overview of current development in electrical energy storage technologies and the application potential in power system operation, Appl. Energy 137, 511 (2015)

3. European Commission, DG ENER Working Paper, The Future Role and Challenges of Energy Storage (2013)

4. S. Kalaiselvam, R. Parameshwaran, Energy storage, Chapter 2, in Thermal Energy Storage Technologies for Sustainability Systems Design, Assessment and Applications (Elsevier Inc., Burlington, 2014)

5. S. Rehman, L.M. Al-Hadhrami, M.M. Alam, Pumped hydro energy storage system: a technological review, Renew. Sustain. Energy Rev. 44, 586 (2015)

6. D. Akinyele, R. Rayudu, Review of energy storage technologies for sustainable power networks, Sustain. Energy Technol. Assess. 8, 74 (2014)

7. L. Wagner, Overview of energy storage technologies, Chapter 27, in Future Energy, Improved, Sustainable and Clean Options for Our Planet, edited by T. Letcher, 2nd edn. (Elsevier Inc., London, 2014)

8. I. Hadjipaschalis, A. Poullikkas, V. Efthimiou, Overview of current and future energy storage technologies for electric power applications, Renew. Sustain. Energy Rev. 13, 1513 (2009)

9. C. Schaber, P. Mazza, R. Hammerschlag, Utility-scale storage of renewable energy, Electr. J. 17, 21 (2004)

10. R.A. Huggins, Energy Storage Fundamentals, Materials and Applications, 2nd edn. (Springer, London, 2016)

11. T. Mahlia, T. Saktisahdan, A. Jannifar, M. Hasan, H. Matseelar, A review of available methods and development on energy storage, Renew. Sustain. Energy Rev. 33, 532 (2014) 
12. H. Zhang, J. Baeyens, G. Cáceres, J. Degrève, Y. Lv, Thermal energy storage: recent developments and practical aspects, Prog. Energy Combust. Sci. 53, 1 (2016)

13. J. Hart, G. Miller, A. Robbins, Small thermal energy storage and its role in our clean energy future, in ACEEE Summer Study on Energy Efficiency in Buildings (2016)

14. N.K.C. Nair, N. Garimella, Battery energy storage systems: assessment for small-scale renewable energy integration, Energy Build. 42, 2124 (2010)

15. Z. Alnasir, M. Kazerani, A small-scale standalone wind energy conversion system featuring SCIG, CSI and a novel storage integration scheme, Renew. Energy 89, 360 (2016)

16. D. Sanchez, Bottling sunlight: using energy storage technology as a lens to view the factors affecting technological change in the electricity supply industry (Australian Council of Learned Academies, 2014)

17. D. Sbordone, L. Martirano, M. Falvo, L. Chiavaroli, B. DiPietra, I. Bertini, A. Genovese, Reactive power control for an energy storage system: a real implementation in a microgrid, J. Network Comput. Appl. 59, 250 (2016)

18. P.E. Dodds, I. Staffell, A.D. Hawkes, F. Li, P. Grunewald, W. McDowall, P. Ekins, Hydrogen and fuel cell technologies for heating: a review, Int. J. Hydrogen Energy 40, 2065 (2015)

19. A. Tallinia, A. Vallati, L. Cedola, Applications of microCAES systems: energy and economic analysis, Energy Proc. 82, 797 (2015)
20. L. Cabeza, I. Martorell, L. Miró, A. Fernández, C. Barreneche, Introduction to thermal energy storage (TES) systems, in Advances in Thermal Energy Storage Systems Methods and Applications, edited by L. Cabeza (Woodhead Publishing Series in Energy, 2015)

21. M. De Koster, Energy Storage - Maturity and Cost of Storage Technologies (2013)

22. O. Leffler, N. Mansour, Energy Storage - A Global Overview and Technological Comparison, Bachelor thesis, KTH School of Industrial Engineering and Management, 2016

23. S. Klepper, Entry, exit, growth, and innovation over the product life cycle, Am. Econ. Rev. 86, 562 (1996)

24. M.S. Whittingham, History, evolution, and future status of energy storage, in Proceedings of the IEEE (2012)

25. International Energy Agency, Key World Energy Statistics (2016)

26. International Electrotechnical Commission, Electrical Energy Storage White Paper (2011)

27. European Commission, Horizon 2020 - Work Programme 2014-2015 General Annexes G-Technology Readiness Levels (2014)

28. AECOM, Energy Storage Study: A Storage Market Review and Recommendations for Funding and Knowledge Sharing Priorities (2015)

29. European Commission, Strategic Energy Technology Plan Study on Energy Education \& Training in EU (2014)

30. International Energy Agency, Technology Roadmap: Energy Storage (2014)

31. SBC Energy Institute, Electricity Storage Factbook (2013)

Cite this article as: Thu-Trang Nguyen, Viktoria Martin, Anders Malmquist, Carlos A.S. Silva, A review on technology maturity of small scale energy storage technologies, Renew. Energy Environ. Sustain. 2, 36 (2017) 